\title{
Tales of the Transatlantic
}

by Anders Stephanson *

Countless conferences and op-ed pieces have been devoted over the years to the Atlantic relationship and its ups and downs, providing ample room for pundits and policy experts to declare what needed to be done to secure this supposedly crucial aspect of international politics. It has been a very dependable worry.

Merely to dismiss the topic, however, would be cynical, in addition to being substantially wrong. Important problems are involved, even when the "relationship" has seemed mainly to exist to provide nourishment for organic intellectuals of the Atlantic establishment. What, for instance, was it, precisely, that was actually being related, and for what purposes? What interests, in particular, came to stand for "America" and "Europe" (the more diffuse of the two entities)? Moreover, as the contretemps over the U.S. thrust into Iraq revealed, geopolitical shifts of the greatest significance are now taking place within the context of this relationship.

The loquacious and undiplomatic Mr. Donald Rumsfeld was thus correct in sensing some kind of basic change in what, from the standpoint of the United States, constitutes Europe, and was therefore correct in also sensing some change in what the relationship might be about. He was also astute in pointing, if only inadvertently, to the fact that, at the very moment when this name - Europe - is being claimed exclusively by the confederation known as the European Union, Europe is actually at its most contradictory. The rattled European response to Rumsfeld's typically tactless remarks indicated just how great the difference is between the claims that are routinely made in the name of Europe and the underlying realities of that ideological sign. It is quite another matter that none of this has much to do with any division between "old" and "new" Europe. "New Europe" for Rumsfeld seemed chiefly to mean those regimes that happened to support the Iraqi policy of his own Republican administration.

It is well to remember under current circumstances just how pleased, on the whole, had been the Europe assembled inside the quarrelsome borders of the EU with the grand policy of the Clinton years. To call it a grand policy may surprise some, given that Clinton often appeared haphazard and aimless in foreign affairs. Yet this was largely only a matter of appearances. Clinton's basic policy, largely a continuation of the policy of Bush the Elder as it had emerged after the nearly instantaneous collapse of his New World Order, was in fact quite coherent: more and better trade liberalization along the lines of NAFTA, the dual centerpiece being the U.S. economy and an overvalued dollar. The

\footnotetext{
* Anders Stephanson is James P. Shenton Associate Professor of the Columbia Core in the History Department at Columbia University in New York.
} 
umbrella under which all of this was being peddled was, it will be recalled, that of globalization and interdependence. A vital but less visible aspect here was the proliferation of the principle of law in private and public affairs alike, what one might refer to as the process of juridification.

The Europeans liked this because it generated economic growth for them courtesy of the imbalanced U.S. economy, along with (Bosnia notwithstanding) international order and predictability in the capitalist heartland. Thus the U.S. posture involved a good deal of consent rather than coercion. It was a classic case of hegemonic rule. Talk of the "indispensable nation" notwithstanding, there was no attempt at messianic redemption of part or all of the globe, and no insistence on any absolute difference between the United States and the rest of the world. The United States was in the world, "leading" the world chiefly through market liberalization.

September 11 shot this pleasant arrangement to pieces, though it had already been undermined by the sharp economic contraction in 2000. But the terrorist attacks opened the way for an astonishingly radical change in the grand policy of the United States, allowing a group of highly articulate right-wing strategists, who had been profoundly alienated from the economistic policies of the 1990 s, to lay out a vision in which, to put it crudely, U.S. hegemony was to be replaced by U.S. supremacy.

The Bush project (as one might call it) looked to the historical eye at first to be a global version of the Roosevelt Corollary to the Monroe Doctrine that is, the extension of a sort of protectorate over the entire world. In 1904, Teddy Roosevelt proclaimed what amounted to a U.S. protectorate over the Caribbean. "Chronic wrongdoing" by Caribbean states would be punished in appropriate ways by the United States (as embodied by the commander-in-chief in the White House). Much discipline and punishment did indeed follow. In return for order and obedience, the Caribbean states would enjoy protection from domestic disorder (here the system failed) and from external, chiefly European, interference.

As the Iraqi operation revealed, however, obedience in exchange for protection was not at all what the Bush Administration was after - there was no desire to extend protection to the entire world in return for obedience. On the contrary, there was a will to command and recast certain parts of the world as the White House saw fit. Obedience was not the issue. Far from protection for everyone, then, the order of the day entailed "regime change," all depending on the whim of the White House.

What permitted this open-ended license at the outset was the war on terrorism, which was never itself an actual war but a pretext that served to legitimate any number of wars, or any other kind of action across state borders that the president might wish to take. If terrorism is not everywhere, it is justification enough that it is potentially everywhere. The White House, then, declared that the United States would act accordingly: Go wherever the threat might lead 
and do whatever it took to wipe it out. And so on. This will to command was in fact the Roman imperium writ large, command in the sense of military supremacy. It was ordering around, rather than order.

To a good number of Europeans (including ordinary Spaniards and Italians), this appeared to be a scenario for instability and lawlessness: a crushing war machine at the imperious disposal of the commander-in-chief; an Iraqi operation that was essentially manufactured, with little initial clamor among the American public; and a White House never chiefly interested in disarming Iraq or ridding it of weapons of mass destruction but in "changing" the regime, and supposedly the rest of the Middle East along with it. Against this, and in the name of international law, critical Europeans consequently opposed attacking Iraq without UN sanction.

Much to the chagrin (one assumes) of George W. Bush and Tony Blair, that view now looks quite appealing. The extraordinarily rosy vision of Iraqis hailing Anglo-Saxon liberators and inspiring Syrians, Iranians, and others to throw out their anti-Western rulers has been replaced by a rather more sober one of extended occupation amid sullen and sometimes lethal hostility. The monumental military supremacy enjoyed by the United States is not easily translated, some have realized, into the kind of massive occupation one would need for proper pacification. At the same time, the legal justification for the invasion has been shown to be embarrassingly flimsy. The architects of U.S. supremacy are still clinging to their long-term aims, the ultimate prize of which is the unalterable subordination of the Chinese regime, which has been explicitly singled out as the one potentially serious threat on the strategic horizon. However, even if the U.S. and its British subalterns manage to fob off responsibility for maintaining "peace" in Iraq to the UN, the fact remains that the grand Bush project is currently stalled. Covert support for oppositional elements in Iran is surely taking place, but one cannot imagine any moves of a high degree of risk in the domain of regime change for quite some time. Whither then the European or Atlantic relationship?

The old system was of course preconditioned on the existence of the Soviet Union and the concomitant division of Europe. Real and imagined, the Soviet threat provided unlimited justification for U.S. interventionism, a system in which the frozen status quo in Europe and the menace it embodied enabled the United States to act anywhere else in the world. NATO, the central Western feature of the European deadlock, expressed the desire among dominant interests on both sides of the Atlantic to maintain a political and military U.S. presence in Western Europe, though, interestingly, the North Atlantic here became ideologically and strategically defined as reaching the Turkish-Iranian border. Serious problems and even crises certainly occurred within the Western camp (Suez, Gaullism, and Ostpolitik, to mention three obvious episodes), but the stark polarity between Moscow and Washington overdetermined European geopolitics and set its limits. No military conflict across the borderline between 
NATO and the Warsaw Pact ever happened, but the always-present threat of one was the pivot of world politics.

The subsequent implosion of the Soviet Union thus meant the implosion of the logic of NATO as well. No serious strategist in the United States believes that Washington would unleash suicidal war for the sake of, say, Lithuania. NATO is now an apparatus without a clear and proper mission. At the same time, as Rumsfeld intimated, the whole concept of Europe is also up for grabs. Marking its boundaries has always been primarily an ideological move, infused with a strong dose of civilizational thinking. Making civilizational sense of Europe was partly the effect of the discovery that it was in fact a fake continent, that it lacked oceanic demarcation: thus the possibility and need to explore other ways of deciding its boundaries. Russia, often in fact the defining factor involved, was deemed to be outside Europe until 1721; then, albeit uncertainly and not in its entirety, inside it until 1917, when the advent of Bolshevism supposedly removed it; then, inside again after 1990. The Cold War had indeed resurrected an old orientalist distinction between Eastern and Western Europe, semantically expressed even now in the distinction in Latinate languages between Oriental and Occidental Europe.

The residual conflicts occurring along these lines, however, are now the preoccupations of Europeans themselves, conflicts centered on the question of who is to be a member of that erstwhile coal and steel union, the European Union, and thus putatively come to qualify as a true or at least normal European. For the dominant U.S. strategists, by contrast, if not for the trade negotiators, Europe has become an abstraction, a variegated map of sometimes useful, sometimes irksome subalterns, a series of virtual constellations as it were, including NATO. In the larger scheme of things, Europe is simply not where the geopolitical action is. Though extremely irritating at times, it is no longer a worry. Short of Blair-like abnegation and eloquent support for Washington, the best Europe from the new perspective is again a divided one, divided not in two but into multiple, contradictory, and overlapping parts.

The one moment of real anxiety on that score during the Iraqi controversy was probably the sudden mirage of a Dreikaiserbund between Paris, Berlin, and Moscow. Such a formation of power would give pause to even the most ardent supremacist. Yet it was immediately apparent that the move was chiefly a gesture, involving as it did the central historical question mark of and for Europe, namely, Russia. Moscow's policy, prudent and cautious in a moment of protracted weakness, has successfully preserved for itself maximum room for maneuver. The so-called Europeans, meanwhile, have yet to resolve the civilizational question of how much of Oriental Europe is to be included in the Real Europe, and whether Islamic Turkey belongs at all. The European Union, the pretensions of its bureaucrats notwithstanding, is not a geopolitical entity proper. Its present head is Silvio Berlusconi.

The actual ground for the coalition of these three states was in any case 
not the idea of a traditional geopolitical counter-formation but the realization, quite rightly, that amidst the processes of juridification and the sanctification of law on the one hand and U.S. military supremacy on the other, the only way to put a damper on Washington's aspirations to command is to insist on proceduralism, as encapsulated above all in the United Nations. This is an explicitly universalist position. Though it has a European lineage, it is in principle neither "Atlantic" nor "European." And so, in the midst of the belated dissolution of the postwar order in Europe, it also signals the end of the Atlantic relationship as we know it. 